\title{
Cellular location and age-dependent changes of the regulatory subunits of cAMP-dependent protein kinase in rat testis
}

\author{
B. F. Landmark ${ }^{1}$, O. Øyen ${ }^{1,2}$, B. S. Skålhegg ${ }^{1,3}$, B. Fauske ${ }^{4}$, \\ T. Jahnsen ${ }^{1,2}$ and V. Hansson ${ }^{1}$ \\ ${ }^{1}$ Institute of Medical Biochemistry, University of Oslo, Nonway; ${ }^{2}$ Institute of Pathology, \\ Rikshospitalet, Oslo, Norway; ${ }^{3}$ Institute of General and Rheumatic Immunology, Rikshospitalet, Oslo, \\ Norway; and ${ }^{4}$ Institute of Anatomy, University of Bergen, Norway
}

\begin{abstract}
This study was undertaken to examine the expression and cellular location of the various cAMP-dependent protein kinase (PKA) subunits in different testicular cell types, using cDNA probes, isoenzyme-specific antibodies and activity measurements. Amounts of mRNA and protein were examined in cultured Sertoli cells, cultured peritubular cells, germ cells (pachytene spermatocytes, round spermatids), Leydig cell tumours as well as whole testes from rats of various ages. In Sertoli cells, there was a good correlation between the amount of mRNA and the respective immunoreactive proteins. In other types of cell, such as germ cells and Leydig tumour cells, this was not always the case. Large amounts of RII $_{\beta}$ mRNA were found in Leydig tumour cells, whereas the amount of immunoreactive protein was low. Furthermore, large amounts of small-sized, germ cell-specific mRNAs for $\mathrm{RI}_{\alpha}(1.7 \mathrm{~kb})$ and $\mathrm{RII}_{\alpha}$ $(2.2 \mathrm{~kb})$ were also found in the developing rat testis after 30 to 40 days of age, but the large amounts of mRNA were only partially reflected at the protein level. Pachytene spermatocytes and round spermatids were practically devoid of both $\mathrm{RII}_{\alpha}$ and $\mathrm{RII}_{\beta}$ protein. During spermatid differentiation, there was a decrease in $\mathrm{RI}_{\alpha}$ and an increase in $\mathrm{RII}_{\alpha}$ protein. Cell specific distribution of the various PKA subunits in testicular cell types is described. In some types of cell, discrepancies between mRNA and protein were demonstrated, which clearly suggest cell specific differences in translational efficiencies for some of these mRNAs, particularly the small-sized mRNAs for $\mathrm{RI}_{\alpha}$ and $\mathrm{RII}_{\alpha}$ in meiotic and post-meiotic germ cells.
\end{abstract}

\section{Introduction}

Testicular function depends on FSH and LH stimulating Sertoli cells and Leydig cells, respectively. These hormones act via cAMP (Robison et al., 1971; Means et al., 1980). Cyclic cAMP is also involved in the regulation of sperm functions such as motility (Tash and Means, 1983; Tash et al., 1984, 1986), epididymal maturation, capacitation (Visconti and Tezòn, 1992) and the acrosome reaction (Hyne and Garbers, 1979; Garbers and Kopf, 1980). Most, if not all, of the effects of cAMP are mediated by the cAMP-dependent protein kinase (PKA) (Beebe and Corbin, 1986). Numerous investigations have thus focused on the role of cAMP and its effector enzyme, PKA in testis (Podesta et al., 1976; Fakunding and Means, 1977; Horowitz et al., 1984; Spruill et al., 1984).

The cAMP-dependent protein kinase (E.C. 2.7.1.37) holoenzyme is a tetrameric complex consisting of a regulatory subunit dimer and two catalytic subunits (Corbin et al., 1978). Several isoforms of PKA have been described. On the basis of their elution positions from DEAE cellulose columns, two major isozymes of PKA were first identified as type I and type II (Corbin et al., 1975). These isozymes were shown to differ in the

Received 9 September 1992 properties of the R subunits (Fleischer et al., 1976). Later, a whole family of PKA subunits, representing distinct gene products, were demonstrated. Four different regulatory subunits $\left(\mathrm{RI}_{\alpha}, \mathrm{RI}_{\beta}, \mathrm{RII}_{\alpha}\right.$ and $\left.\mathrm{RII}_{\beta}\right)$ but only one catalytic $\left(\mathrm{C}_{\alpha}\right)$ subunit has so far been identified in rat tissues (Kuno et al., 1987; Scott et al., 1987; Sandberg et al., 1988; Massa et al., 1990; Landmark et al., 1991; Wiemann et al., 1991). Very small amounts of mRNA $(4.7 \mathrm{~kb})$ for another catalytic subunit, $C_{\beta}$, have also been demonstrated in rat testis using a human cDNA probe (Øyen et al., 1990), but the corresponding protein has not been demonstrated. In addition, a cDNA for a third catalytic subunit of PKA $\left(C_{\gamma}\right)$ was isolated from human testis (Beebe et al., 1990). This subunit has not been detected in any other organ or species.

Studies based on ion-exchange chromatography and photoaffinity labelling have shown that there are two types of PKA in rat Sertoli cells (Spruill et al., 1984; Nistico et al., 1991), rat Leydig cells (Winters and Dufau, 1984), peritubular cells (Nistico et al., 1991) and spermatozoa (Horowitz et al., 1984, 1989; Atherton et al., 1985; Tash et al., 1986). These methods have certain limitations in that they do not separate the $\alpha$ and $\beta$ forms of $\mathrm{R}$ or $\mathrm{C}$. With the advent of cDNA probes, the distinction between $\alpha$ and $\beta$ forms was available at the mRNA level (Øyen et al., 1987a, 1988a; Skålhegg et al., 1992a). Specificity at 
the protein level was achieved by the development of subunit specific antibodies (Skålhegg et al., 1992b; Lohmann et al., 1983). In the present report, mRNA and protein expression of all known isoforms of PKA has been studied in whole rat testis during development and in isolated testicular cells.

\section{Materials and Methods}

\section{Sertoli and peritubular cells}

Primary cultures of Sertoli cells and peritubular cells were prepared from testes of 19-day-old immature rats (SpragueDawley), and treated as described by Dorrington et al. (1975) and Øyen et al. (1988a). Experiments on Sertoli cells were started on day 4 after plating. Fresh medium was added $12 \mathrm{~h}$ before stimulation and changed at stimulation and after $24 \mathrm{~h}$. The overall purity was estimated to be $90-95 \%$. The peritubular cells were harvested when confluent, after 10-12 days of culture.

\section{Preparation of germinal cell fractions}

Germ cells (pachytene spermatocytes, round spermatids) were isolated from seminiferous tubules of 32-day-old rats. Germ cells enriched in elongating spermatids were obtained by using seminiferous tubules from 44-day-old rats. A cell preparation was obtained by consecutive collagenase, trypsin, DNase and mechanical treatment and separation by a BSA gradient using a Sta-Put unit (Øyen et al., 1988a, b). Purity of the cell fractions was assessed as described by $\emptyset$ yen et al. (1987b) and was $85-90 \%$ for pachytene spermatocytes, and $80-85 \%$ for round spermatids of the total cell number. The impurities in these fractions were accounted for by Sertoli cells, interstitial cells and germinal cells at other stages of spermatogenesis.

\section{Leydig cell tumour}

Leydig cell tumour (H-540), $1 \mathrm{ml}$, disintegrated in $0.9 \% \mathrm{NaCl}$, was transplanted s.c. onto the back of 30-35-day-old SpragueDawley rats. After 2-3 weeks, the rats were killed by decapitation. The tumours were excised immediately and stored in liquid nitrogen until use (Erichsen et al., 1984).

\section{Whole testis preparation}

Sprague-Dawley rats of different ages were decapitated. For the age study, 3-10 rats of each age were used. Testes were dissected free, removed, immediately frozen in liquid nitrogen and stored at $-75^{\circ} \mathrm{C}$.

\section{RNA extraction and northern transfer}

RNA extraction and northern analysis were performed as described by Maniatis et al. (1983) and Landmark et al. (1991). RNA was determined by measuring absorbance at 260,280 and $310 \mathrm{~nm}$, and quantification was based on the $260 \mathrm{~nm}$ reading.
Twenty micrograms of total RNA was loaded per lane. The RNA-agarose gels were stained with ethidium bromide before blotting to evaluate RNA amount and quality.

\section{cDNA probes}

The mouse $\mathrm{RI}_{\alpha}$ probe was a $0.6 \mathrm{~kb}$ Pstl fragment (provided by Stanley McKnight, Seattle, WA), entirely from inside the open reading frame. To probe for $\mathrm{RII}_{\alpha}$ mRNA, a $0.7 \mathrm{~kb}$ rat cDNA probe (Sacl-Bgli fragment, all within the open reading frame) was used. RII $_{\beta}$ mRNA was probed using a $1.5 \mathrm{~kb}$ rat cDNA containing the $3^{\prime}$-coding $(1.2 \mathrm{~kb})$ and non-coding $(0.3 \mathrm{~kb})$ region (Jahnsen et al., 1986). For $C_{a^{\prime}}$ a $0.6 \mathrm{~kb}$ EcoRI fragment (mouse) was used which contained a $3^{\prime}$-coding region and about 160 base pairs of $3^{\prime}$-non-coding sequence (Uhler et al., 1986).

\section{Preparation of cell extracts}

Cells were homogenized in PE buffer $(10 \mathrm{mmol}$ potassium phosphate $\mathrm{l}^{-1}, 1 \mathrm{mmol}$ EDTA $\mathrm{l}^{-1}, \mathrm{pH} 6.8$ ) with $150 \mathrm{mmol}$ $\mathrm{NaCl} \mathrm{l}^{-1}$ (PEN) containing the protease inhibitors chymostatin, antipain, leupeptin and pepstatin $\left(10 \mu \mathrm{g} \mathrm{ml}^{-1}\right.$ each)). Before homogenization, Sertoli cells in culture dishes were washed with $3 \times 5 \mathrm{ml}$ Eagle's modified minimal essential medium, then reincubated in a large volume $(30-50 \mathrm{ml})$ of media for $1 \mathrm{~h}$ to remove cAMP before cAMP-binding experiments. The culture dishes were cooled for 15 min on ice, washed with $3 \times 5 \mathrm{ml}$ PEN buffer and scraped into $0.5 \mathrm{ml}$ PES containing protease inhibitors.

Whole testis and Leydig cell tumour tissue were fragmented while frozen and then homogenized in 8 volumes $(w / v)$ of PEN buffer. Sta-Put-fractionated germ cells were homogenized in four volumes $(w / v)$ of PEN buffer. Homogenization was performed by 15 plus 10 strokes with a tight-fitting Dounce homogenizer. Supernatants were prepared by centrifugation for $60 \mathrm{~min}$ at $100000 \mathrm{~g}$, at $4^{\circ} \mathrm{C}$. Aliquots were frozen in liquid nitrogen and stored at $-75^{\circ} \mathrm{C}$. Protein concentration was determined by the method of Bradford (1976), using BSA as standard.

\section{cAMP-binding, protein kinase activity and determination of $R: C$ ratio}

These assays were performed as described by Cobb and Corbin (1988). The levels of $R$ were determined by specific $\left[{ }^{3} \mathrm{H}\right] \mathrm{cAMP}$ binding (assuming two cAMP binding sites per monomer, (Corbin et al., 1986)).

\section{$D E A E$-cellulose chromatography}

Whatman DE52 columns $(0.9 \times 7.5 \mathrm{~cm}, 4.8 \mathrm{ml})$ were equilibrated with PE buffer ( $\mathrm{pH}$ 6.8). Extracts for application to DEAE columns were prepared in PE buffer with $250 \mathrm{mmol}$ sucrose $\mathrm{I}^{-1}$ (PES). Round spermatids ( $1.6 \mathrm{mg}$ of soluble protein) from 32-dayold rats and a fraction of haploid cells containing spermatids at different stages of elongation from 44 -day-old rats $(2.9 \mathrm{mg}$ soluble protein) were applied in a volume of $800 \mu$ l. Linear salt 
gradients $\left(0-0.4 \mathrm{~mol} \mathrm{NaCl} \mathrm{l} \mathrm{N}^{-1}\right.$, total volume $\left.50 \mathrm{ml}\right)$ were created with a Büchler Instruments $25070 \mathrm{~A}$ gradient mixer. Each column was washed with $30 \mathrm{ml}$ (about six bed volumes) PE buffer, before starting the gradient and fractions of $0.5 \mathrm{ml}$ were collected. Kinase assays and cAMP binding assays were performed immediately following elution. The $\mathrm{NaCl}$ concentrations were determined by conductivity measurements.

\section{Protein gel electrophoresis and western blotting}

Denaturing polyacrylamide gel electrophoresis was performed using slab gels containing either $7.5 \%$ (for $R$ subunits) or $10 \%$ (for $C$ subunits) polyacrylamide in the separating gel and $4.5 \%$ polyacrylamide in the stacking gel (Laemmli, 1970; Landmark et al., 1991). The samples were denatured by boiling for $2 \mathrm{~min}$ in a solution containing final concentrations of $1.4 \%$ SDS, $20 \% \beta$-mercapto-ethanol and $0.05 \%$ bromophenol blue. Western blotting was performed as described by Towbin et al. (1988) and Landmark et al. (1991).

\section{Radioimmunolabelling}

Radioimmunolabelling of western blots using specific antibodies for the different $\mathrm{R}$ subunits was performed using ${ }^{125}$ I-labelled $\operatorname{IgG}$ as described by Jahnsen et al. (1985). The specificities of the antibodies against rat $\mathrm{RII}_{\alpha^{\prime}} \mathrm{RII}_{\beta}$ and $\mathrm{C}$ have been described by Lohmann et al. (1983). Affinity purified antisera against rat $\mathrm{RI}_{\alpha}$ were provided by $\mathrm{S}$. $\mathrm{O}$. Døskeland (Institute of Anatomy, University of Bergen).

\section{Immunoquantitation}

RI and total RII were measured by immunoabsorption on protein A-Sepharose. Samples were equilibrated with $\left[{ }^{3} \mathrm{H}\right] \mathrm{cAMP}$, and antisera against RI or RII were added. Immunoabsorbed R was estimated by counting $\left[{ }^{3} \mathrm{H}\right] \mathrm{cAMP}$ eluted by 1 mol acetic acid $l^{-1}$ as described by Ekanger et al. (1988).

\section{Materials}

$\left[{ }^{3} \mathrm{H}\right] \mathrm{CAMP}, 34 \mathrm{Ci} \mathrm{mmol}^{-1}$, (TRK.498) and $\gamma-\left[{ }^{32} \mathrm{P}\right] \mathrm{ATP}$ (about $5000 \mathrm{Ci} \mathrm{mmol}^{-1}$, PB 10 218) were purchased from Amersham (Bucks) and goat anti-rabbit $\left[{ }^{125} \mathrm{I}\right]-\mathrm{IgG}\left(7.6 \mu \mathrm{Ci} \mu \mathrm{g}^{-1}, \mathrm{NEX}-155\right)$ was obtained from NEN Research (Boston, MA). $N^{6}-2^{\prime}-O$ dibutyryl adenosine $3^{\prime} 5^{\prime}$ cyclic monophosphate (D-0627), adenosine triphosphate grade I (A-2383), adenosine $3^{\prime} 5^{\prime}$ cyclic monophosphate (A-4137), aprotinin (A-6279), Triton X-100 (T-6878), Nonidet P-40 (N-3516), DNase (D-0876), collagenase (C-0130) and histone (calf thymus) Type II-AS were from Sigma (St Louis, MO). Pepstatin A (4039), leupeptin (4041), antipain (4062), chymostatin (4063) and Kemptide phosphate acceptor protein (8065) were purchased from Peninsula Laboratories (Belmont, CA). Agarose (5510 UA) was from Bethesda Research Laboratories (Gaithersburg, MD). Protein-A Sepharose CL-4B was from Pharmacia (Bromma). DEAE cellulose (DE52) was purchased from Whatman (Maidstone). Non-fat dry milk (Molico) was bought from Nestlé (Vevey). Bradford protein assay reagent (500-0006) was bought from Bio-Rad (Richmond,

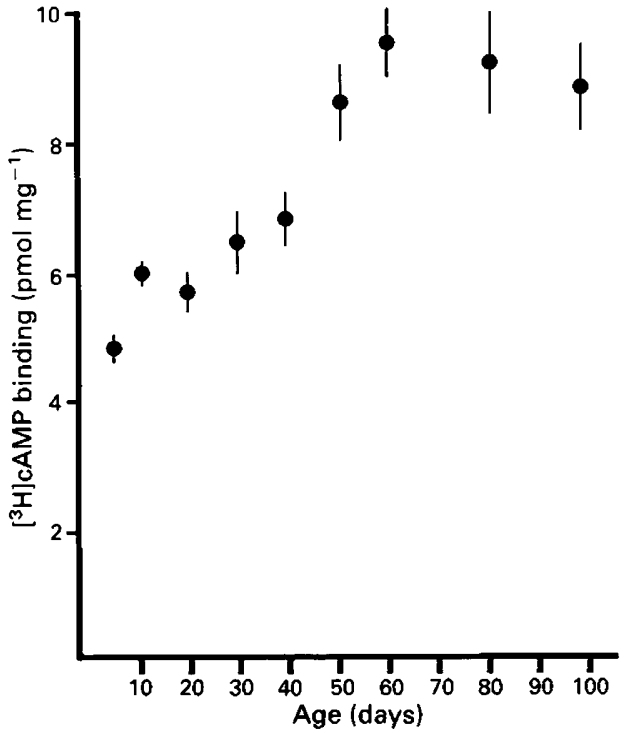

Fig. 1. Specific binding of $\left[{ }^{3} \mathrm{H}\right] \mathrm{cAMP}$ in extracts from whole testes. Testes were removed from rats at different ages (days), homogenized, and specific $\left[{ }^{3} \mathrm{H}\right] \mathrm{cAMP}$ binding was determined in $100000 \mathrm{~g}$ supernatants. Each point represents the mean of three experiments \pm SEM.

CA). Penicillin was obtained from Apothekernes Laboratorium (Oslo), streptomycin from Heyl (Berlin) and fungizone from Novo Industries (E. R. Squibbs and Sons, Princeton, NJ). Fetal calf serum (011-06290), Eagles minimum essential medium (041-01090) and Hanks balanced salt solution without $\mathrm{Ca}^{2+}$ and $\mathrm{Mg}^{2+}$ (041-04140) were purchased from Gibco (Grand Island, NY). Sodium dodecyl sulfate (161-0301), acrylamide (161-0101), $N^{\prime}, N^{\prime}$,-methylene-bis-acrylamide (161-0201), N,N,N', $N^{\prime}$-tetramethylenediamine (161-0800), ammonium persulfate (1610700), tris(hydroxymethyl)aminomethane (161-0716), glycine (161-0718), bromophenol blue (161-0404) and Coomassie blue R250 (161-0400) were obtained from BioRad. All other chemicals were of analytical grade.

\section{Results}

\section{$\left[{ }^{3} H\right] c A M P$ binding capacity}

Extracts (100000 $\mathrm{g}$ supernatants) were prepared from rat testes of the given ages and total R-subunit activity was assayed by specific $\left[{ }^{3} \mathrm{H}\right] \mathrm{cAMP}$ binding (Fig. 1). Specific $\left[{ }^{3} \mathrm{H}\right] \mathrm{cAMP}$ binding in 5-day-old rats was relatively low (approximately $5 \mathrm{pmol} \mathrm{mg}^{-1}$ ). The total amount of regulatory subunit in testis showed little change between 10 and 30 days of age ( $6 \mathrm{pmol} \mathrm{mg}^{-1}$ ). From 30 to 60 days there was an increase in $\left.{ }^{3} \mathrm{H}\right] \mathrm{cAMP}$-binding activity which reached a maximum of approximately $9.5 \mathrm{pmol}^{-1}$ at 60 days.

\section{Age-dependent variation in $R I_{a} m R N A$ and protein}

A mouse cDNA probe $(0.6 \mathrm{~kb})$, specific for the $\mathrm{RI}_{\alpha}$ subunit, detected three mRNA bands of $3.2,2.9$ and $1.7 \mathrm{~kb}$ (Fig. 2a). The two larger mRNAs (2.9 and $3.2 \mathrm{~kb}$ ) declined slightly after 
(a)

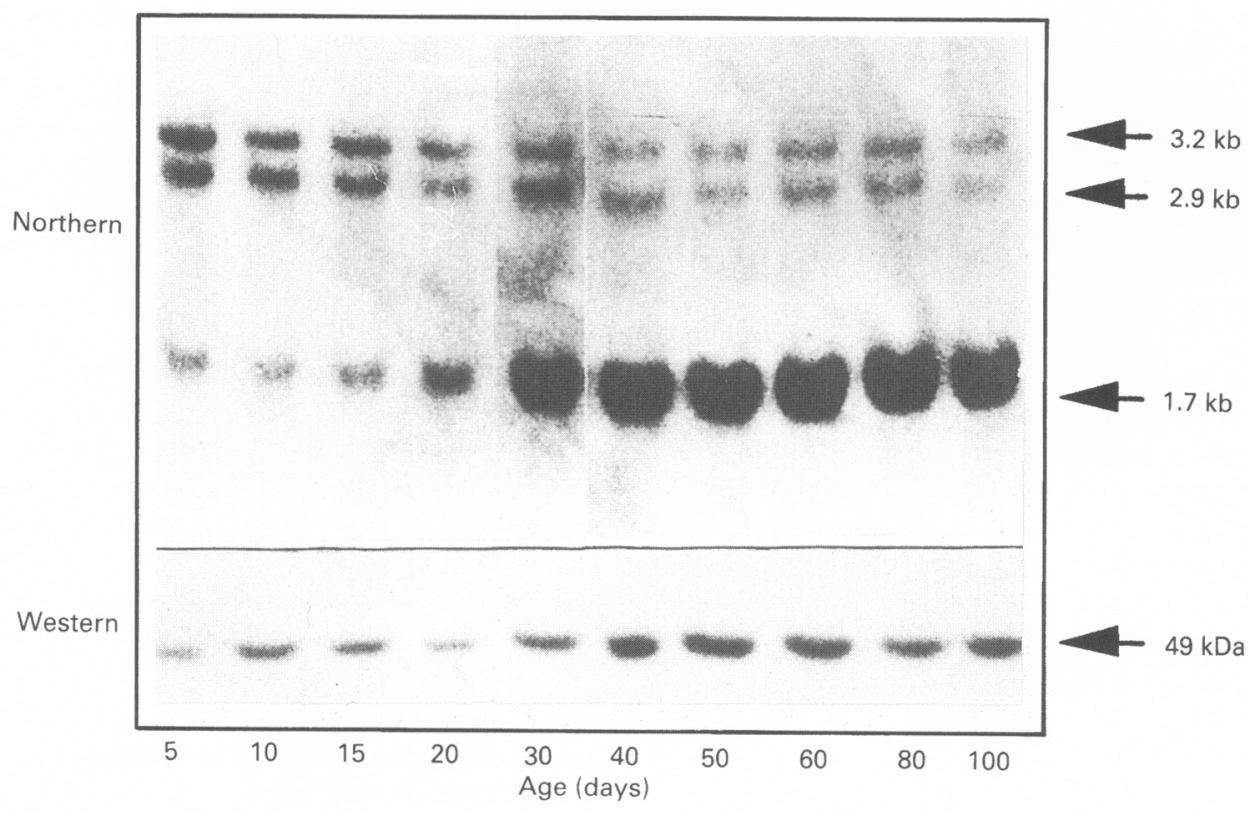

(b)

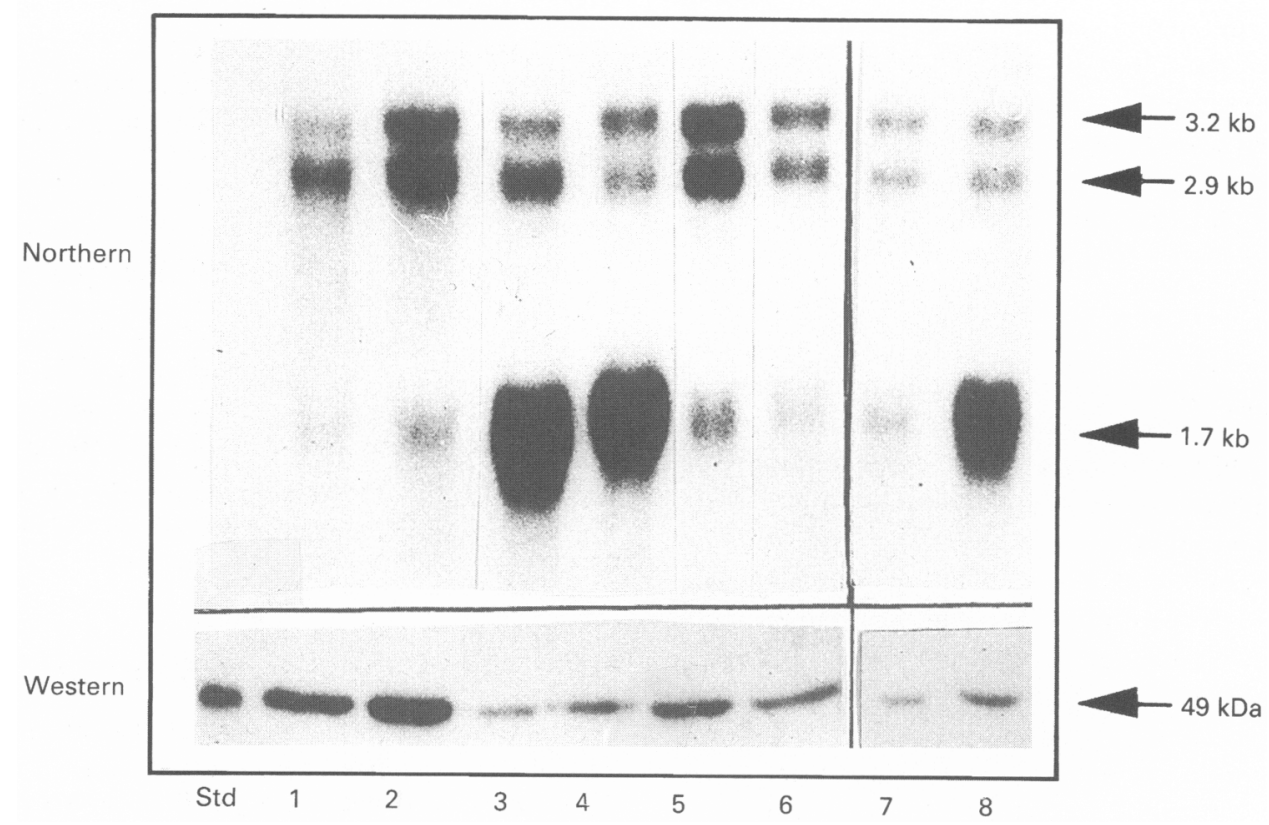

Fig. 2. (a) Age-dependent changes in $\mathrm{RI}_{\alpha}$ mRNA (northern) and protein (western) in rat testis. Total RNA was purified, separated on $1.5 \%$ agarose gels $(20 \mu \mathrm{g}$ per lane), blotted to nylon filters, probed with ${ }^{32} \mathrm{P}$-labelled cDNA for $\mathrm{RI}_{\alpha}$ and exposed for autoradiography. Soluble proteins were extracted, separated on one-dimensional SDS-PAGE (7.5\%, 4.5\% stacking gel), electroblotted to nitrocellulose filters and probed with specific antisera. After radioimmunolabelling, autoradiograms were prepared. (b) Cell-specific distribution of $\mathrm{RI}_{\alpha}$ mRNA (northern) and protein (western) in rat testis. Lane 1: unstimulated Sertoli cells from 19-day-old rats. Lane 2: Sertoli cells stimulated with dibutyryl cAMP $\left(0.1 \mathrm{mmol}^{-1}\right)$ for $48 \mathrm{~h}$. Lane 3 : pachytene spermatocytes from 32-day-old rats. Lane 4: round spermatids from 32-day-old rats. Lane 5: peritubular cells. Lane 6: Leydig cell tumour. Lane 7: testis from 19-day-old rats. Lane 8: testis from 32-day-old rats. Std: purified rabbit skeletal muscle $\mathrm{RI}_{\alpha}$.

30 days of age, coinciding with a high expression of a $1.7 \mathrm{~kb} \mathrm{RI} \mathrm{I}_{\alpha}$ mRNA previously shown to be specific for pachytene spermatocytes and round spermatids (Øyen et al., 1988b). Immunoreactive
$\mathrm{RI}_{\alpha}$ protein (Fig. 2a, western) also increased after 20 days of age. The relative increase in $R I_{\alpha}$ protein appears to be much less than that for the $1.7 \mathrm{~kb}$ mRNA band. 


\section{Cell-specific expression of $R I_{a} m R N A$ and protein}

Three mRNAs $(3.2,2.9$ and $1.7 \mathrm{~kb})$ were detected in rat testis, but in various relative densities in the different cell types (Fig. $2 \mathrm{~b}$, upper panel). The two larger bands $(2.9$ and $3.2 \mathrm{~kb}$ ) were primarily expressed in the somatic cells of the testis (Sertoli cells, peritubular cells and tumour Leydig cells) (Fig. 3), whereas the smaller $1.7 \mathrm{~kb} \mathrm{RI}_{\alpha}$ mRNA revealed high expression in pachytene spermatocytes (lane 3) and round spermatids (lane 4). The dramatic increase in the $1.7 \mathrm{~kb}$ mRNA for $\mathrm{RI}_{\alpha}$ in whole testis from day 20 (lane 7) to day 30 (lane 8 ) reflects the increase in these types of germ cell during this period. $\mathrm{RI}_{\alpha} \mathrm{mRNA}$ and protein in Sertoli cells (lanes 1 and 2) were stimulated 2-3-fold by dibutyryl cAMP $\left(0.1 \mathrm{mmol} \mathrm{l}^{-1}\right)$. Furthermore, immunoreactive $\mathrm{RI}_{\alpha}$ was detected in all types of testicular cell. Greatest amounts were seen in Sertoli cells (lanes $I$ and 2) and peritubular cells (lane 5). There was much less immunoreactive $\mathrm{RI}_{\alpha}$ in germ cells, in spite of the fact that mRNA content for this subunit of PKA was highest in these cells (lanes 3 and 4). The standard is purified rabbit skeletal muscle $\mathrm{RI}$, which migrates with an apparent molecular mass of $49 \mathrm{kDa}$.

\section{Age-dependent variation in RII $_{a} m R N A$ and protein}

In whole testis, a single $\mathrm{RII}_{a}$ band of $0.6 \mathrm{~kb}$ was present up to 40 days of age (Fig. 3a). The intensity of this band decreased with age of the animal. From 40 days of age, high expression of a smaller $2.2 \mathrm{~kb}$ band was observed. For immunoreactive RII $_{\alpha^{\prime}}$ a single protein band migrating at $54 \mathrm{kDa}$ was detected at all ages (lower panel, Fig. 3a). In spite of the dramatic increase in the $\mathrm{RII}_{\alpha}$ mRNA $(2.2 \mathrm{~kb})$ after 40 days of age, only a small increase in RII $_{\alpha}$ protein was observed.

\section{Cell-specific expression of $R I I_{a}$}

The $\operatorname{RII}_{\alpha} 6.0 \mathrm{~kb}$ mRNA was detected in various amounts (Fig. 3b). The peritubular cell fraction (lane 5) had the greatest amount; intermediate amounts were found in cAMP-treated Sertoli cells (lane 2) and Leydig cells (lane 6). RII $\alpha$ mRNA was below the level of detection in unstimulated Sertoli cells (lane 1), pachytene spermatocytes and round spermatids from 32day-old rats (lanes 3 and 4). Further exposure of this filter resulted in a clear $\operatorname{RII}_{\alpha}(6.0 \mathrm{~kb})$ signal also in unstimulated Sertoli cells, which shows a slight increase to lane 2 . This increase is not reflected at the protein level (Landmark et al., 1991). The same cell fractions were examined with respect to RII $_{\alpha}$ protein (Fig. 3b). The standard is RII purified from rat brain. Large amounts of immunoreactive $\mathrm{RII}_{\alpha}$ were found in whole testis (lanes 7 and 8), Sertoli cells (lanes 1 and 2) and peritubular cells (lane 5). In tumour Leydig cells (lane 6), a smaller immunoreactive $\mathrm{RII}_{\alpha}$ protein was observed, probably representing a proteolytic degradation product of $\mathrm{RII}_{\alpha}$ (lane 6). No immunoreactive $\mathrm{RII}_{\alpha}$ was observed in either of the germ cell fractions (lanes 3 and 4).

\section{Age-dependent variation of $R I_{\beta} m R N A$ and protein}

A single band of $\operatorname{RII}_{\beta}$ mRNA $(3.2 \mathrm{~kb})$ was observed before 40 days of age (Fig. $4 a$ ). After 40 days of age, variable amounts of a smaller $\mathrm{RII}_{\beta}$ mRNA $(1.9 \mathrm{~kb})$ were observed. There was a discrepancy between RII $_{\beta}$ mRNA and immunoreactive protein in that maximum amounts of $\operatorname{RII}_{\beta}$ mRNA were seen at 30 days of age, an age at which there is little $\mathrm{RII}_{\beta}$ protein. After 40 days of age slightly less $\mathrm{RII}_{\beta}$ mRNA and protein were observed.

\section{Cell-specific expression of RI $_{\beta} m R N A$ and protein}

Abundant $\mathrm{RII}_{\beta}$ mRNA was found in stimulated $(0.1 \mathrm{mmol}$ dibutyryl cAMP ${ }^{-1}$ ) Sertoli cells (lane 2) and in tumour Leydig cells (lane 6). Significant $\mathrm{RII}_{\beta}$ mRNA signals were also present in peritubular cells (lane 5), the fraction of germ cells containing round spermatids (lane 4 ) and in whole testis from 20- and 30day-old rats. The $1.9 \mathrm{~kb}$ band was most clearly visible in tumour Leydig cells (lane 6). There was a remarkable difference in $\mathrm{RII}_{\beta}$ content between unstimulated (lane 1) and stimulated (lane 2) Sertoli cells. The increase in RII $_{\beta}$ mRNA after dibutyryl cAMP stimulation was more than 50-fold. On the western blot, (Fig. 4b, lower panel), the same cell fractions were probed with a specific anti-RII $\beta$ antiserum. A single band migrating with an apparent molecular mass of $52 \mathrm{kDa}$ was detected. Whereas the cAMP stimulated Sertoli cells (lane 2 ) gave a clear $\mathrm{RII}_{\beta}$ signal, immunoreactive $\mathrm{RII}_{\beta}$ could not be detected in the unstimulated Sertoli cells. Unstimulated Sertoli cells (lane I), pachytene spermatocytes (lane 3), round spermatids (lane 4) and peritubular cells were practically devoid of $\mathrm{RII}_{\beta}$ protein. In contrast to the abundance of $\mathrm{RII}_{\beta} \mathrm{mRNA}$ in tumour Leydig cells, there was relatively little $\mathrm{RII}_{\beta}$ protein.

\section{Age-dependent variation of $C_{a} m R N A$ and protein}

When the northern filter was probed with $\mathrm{C}_{\alpha} \mathrm{cDNA}$, a single mRNA at $2.4 \mathrm{~kb}$ was detected (Fig. 5a). This mRNA increased from 30 days of age and onwards. The anti-C antiserum (Fig. 5a, lower panel) detected a band with an apparent molecular mass of $40 \mathrm{kDa}$. Whereas there was an abrupt increase in $\mathrm{C}_{a} \mathrm{mRNA}$ between 20 and 30 days of age, the increase in $C_{\alpha}$ protein was observed from day 40 and onwards.

\section{Cell-specific expression of $C_{\alpha} m R N A$ and protein}

$C_{a}$ mRNA was present in all of the cell fractions examined (Fig. 5b); the greatest amount was found in the germ-cell fractions (lanes 3 and 4), Leydig cell tumour and in whole testis from 30 days of age (lane 8 ). $C_{a}$ mRNA content of Sertoli cells (lanes 1 and 2), peritubular cells (lane 5) and 20-day-old testis was somewhat lower. In general, $\mathrm{C}_{\alpha}$ protein showed a similar variation and highest amounts of immunoreactive protein were seen in the germ-cell fractions (lanes 3 and 4). Neither $C_{\alpha}$ protein nor mRNA in Sertoli cells were influenced by cAMP treatment.

\section{Expression of $R I_{a}$ and $R I I_{a} m R N A$ and protein during germ cell differentiation}

As shown above (Fig. 2b), significant amounts of $\mathrm{RI}_{\alpha}$ mRNA $(1.7 \mathrm{~kb})$ and protein were observed in pachytene spermatocytes (PS) and round spermatids (RST), isolated from 32-day-old rats. 
(a)

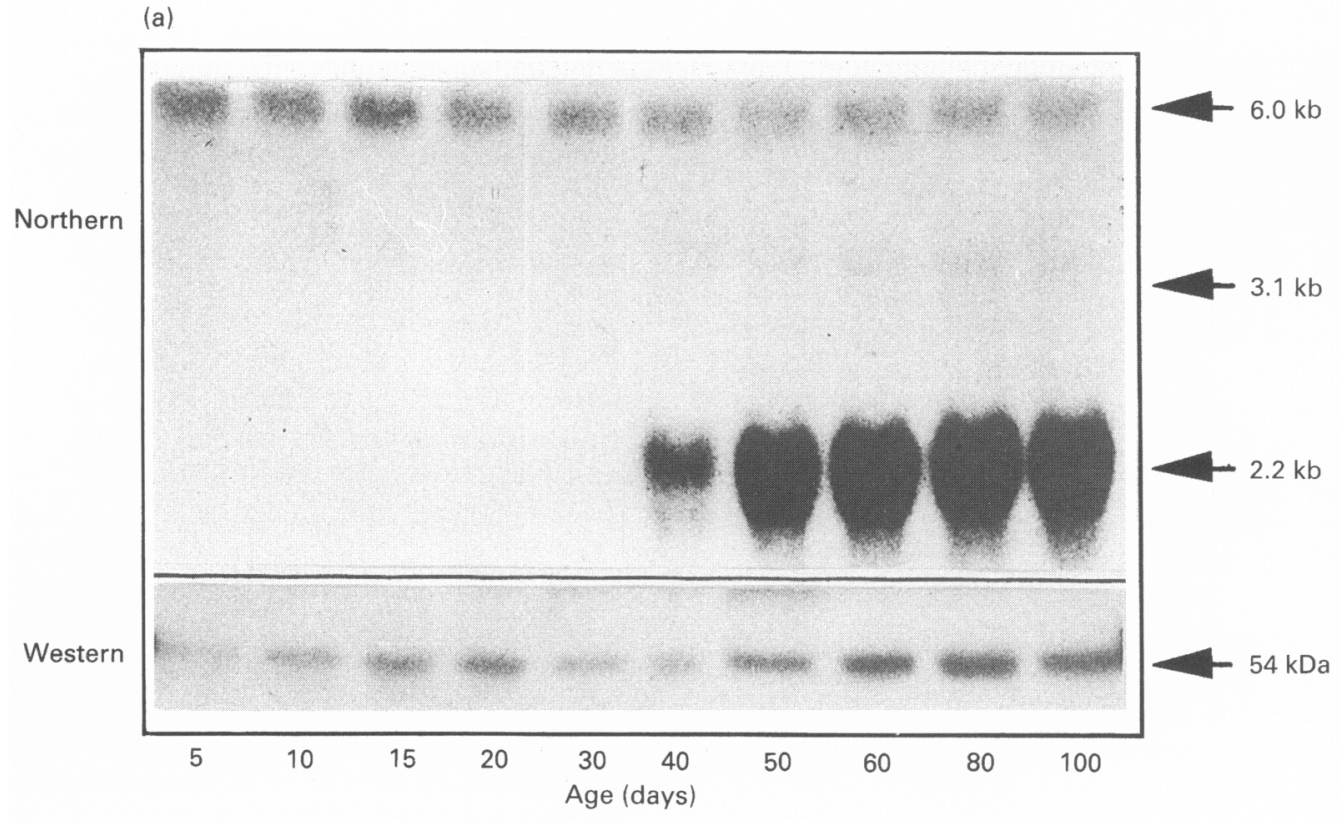

(b)

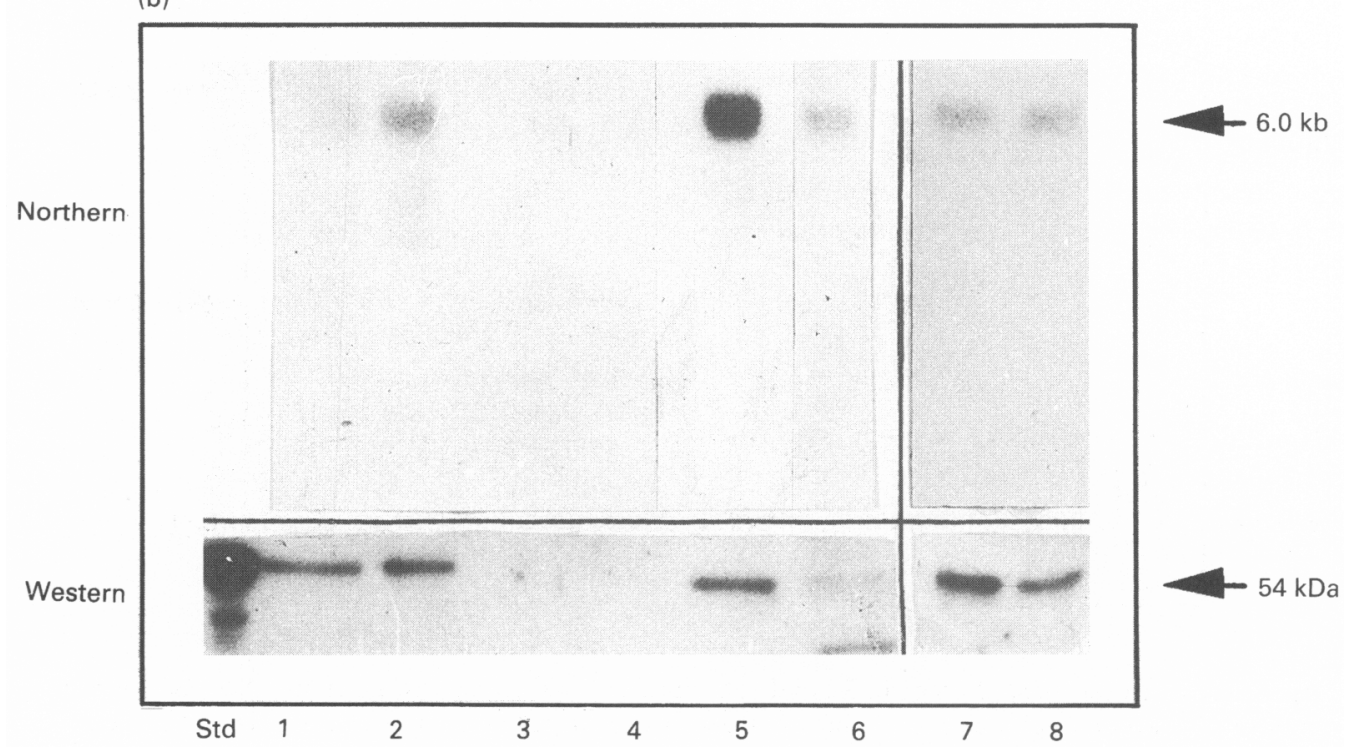

Fig. 3. (a) Age-dependent changes in $\mathrm{RII}_{\alpha} \mathrm{mRNA}$ (northern) and protein (western) in rat testis. Twenty micrograms of total RNA was loaded onto each lane, and the resulting filter was probed with ${ }^{32} \mathrm{P}$-labelled cDNA for $\mathrm{RII}_{\alpha}$ and exposed for autoradiography. Soluble proteins were extracted, separated on one-dimensional SDS-PAGE $(7.5 \%, 4.5 \%$ stacking gel), electroblotted to nitrocellulose filters and probed with specific antisera. After radioimmunolabelling, autoradiograms were prepared. (b) Cell-specific distribution of RII $\mathrm{mRNA}$ (northern) and protein (western) in rat testis. Lane I: unstimulated Sertoli cells from 19-day-old rats. Lane 2: Sertoli cells stimulated with dibutyryl cAMP $\left(0.1 \mathrm{mmol}^{-1}\right)$ for $48 \mathrm{~h}$. Lane 3: pachytene spermatocytes from 32-day-old rats. Lane 4: round spermatids from 32-day-old rats. Lane 5: peritubular cells. Lane 6: Leydig cell tumour. Lane 7: testis from 19-day-old rats. Lane 8: testis from 32-day-old rats. Std: purified rat ovary RII.

In contrast, RII $_{\alpha}$ mRNA $(2.2 \mathrm{~kb})$ and protein were not detected (Fig. 3b). The $1.7 \mathrm{~kb} \mathrm{RI}$ mRNA was already present at 20 days of age (Figs 2a, 3a), whereas the $2.2 \mathrm{~kb} \mathrm{RII}_{a}$ mRNA first appeared at day 40 . At this age the spermatids have begun to elongate. We therefore examined mRNA and protein for
$\mathrm{RI}_{\alpha}$ and $\mathrm{RII}_{\alpha}$ in pachytene spermatocytes and round spermatids in cells isolated from rats of 32 and 44 days of age. From 44-day-old rats, a fraction rich in elongating spermatids was also isolated. Levels of immunoreactive $\mathrm{RI}_{\alpha}$ in PS and RST were higher in cells from 44-day-old rats than in cells from 
(a)

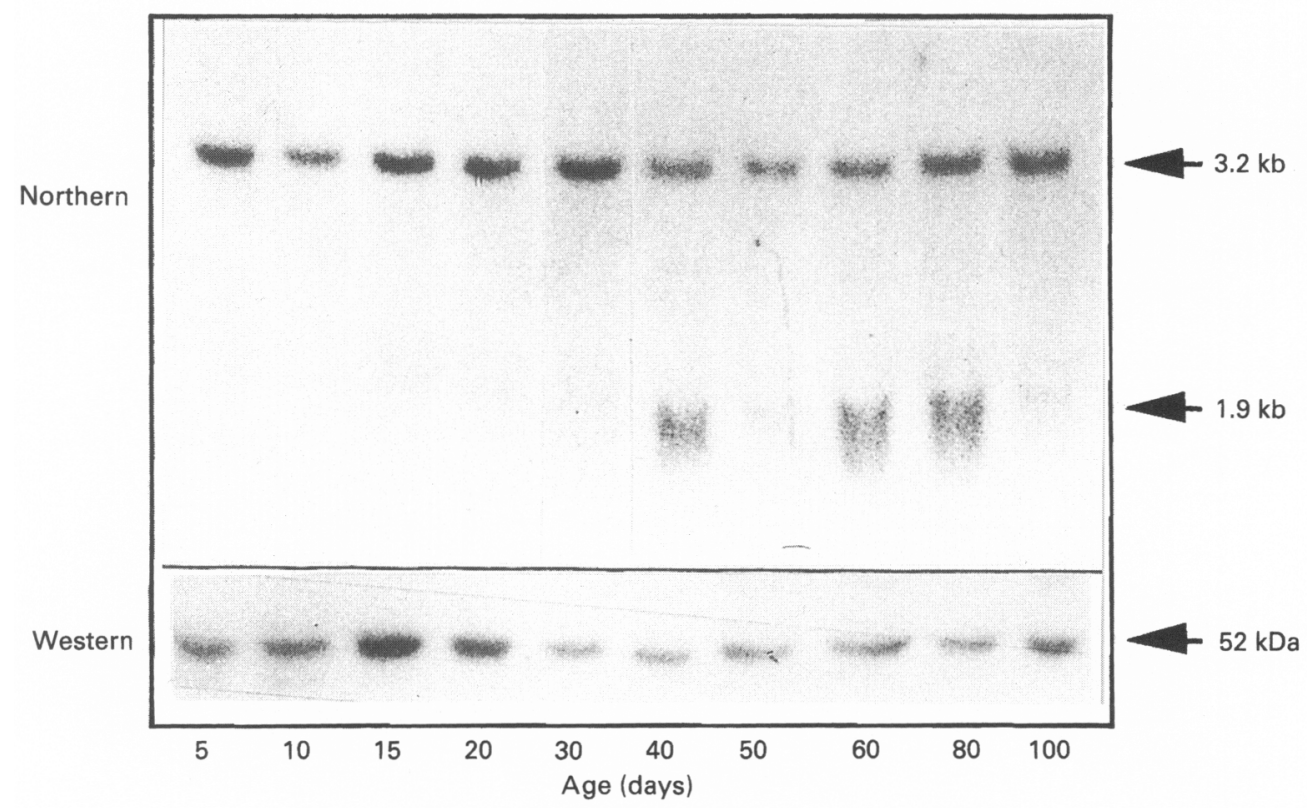

(b)

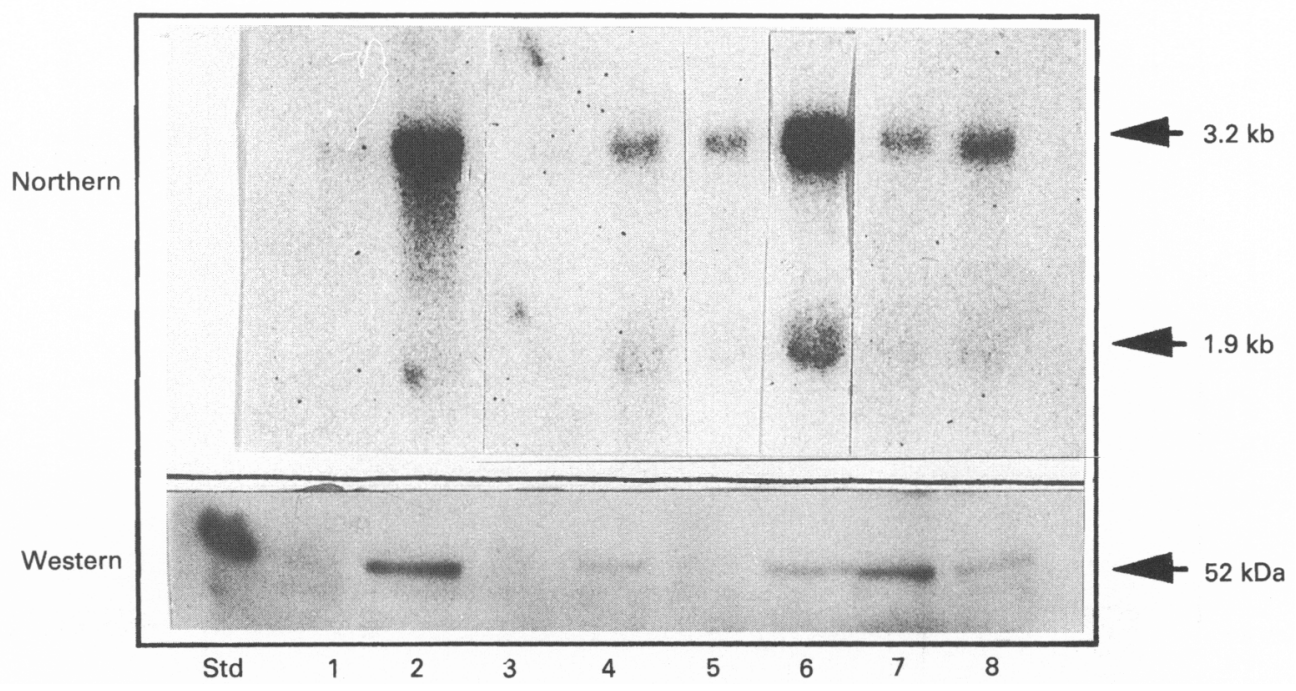

Fig. 4. (a) Age-dependent changes in $\mathrm{RII}_{\beta} \mathrm{mRNA}$ (northern) and protein (western) in rat testis. Twenty micrograms of total RNA was loaded onto each lane, and the resulting filter was probed with ${ }^{32} \mathrm{P}$-labelled cDNA for $\mathrm{RII}_{\beta}$ and exposed for autoradiography. Soluble proteins were extracted, separated on onedimensional SDS-PAGE (7.5\%, 4.5\% stacking gel), electroblotted to nitrocellulose filters and probed with specific antisera. After radioimmunolabelling, autoradiograms were prepared. (b) Cell-specific distribution of $\mathrm{RII}_{\beta}$ mRNA (northern) and protein (western) in rat testis. Lane I: unstimulated Sertoli cells from 19-day-old rats. Lane 2: Sertoli cells stimulated with dibutyryl cAMP $\left(0.1 \mathrm{mmol}^{-1}\right)$ for $48 \mathrm{~h}$. Lane 3: pachytene spermatocytes from 32-day-old rats. Lane 4: round spermatids from 32-day-old rats. Lane 5: peritubular cells. Lane 6: Leydig cell tumour. Lane 7: testis from 19-day-old rats. Lane 8: testis from 32-day-old rats. Std: purified rat ovary RIl.

32-day-old rats, but revealed a clear decrease in elongating spermatids (ES) (Fig. 6). In contrast, neither RII ${ }_{\alpha}$ mRNA nor protein were detected in germ cells (PS, RST) from 32-day-old rats (Fig. 7). Coinciding with increasing $\mathrm{RI}_{\alpha}$ mRNA (2.2 kb) in elongating spermatids (ES), immunoreactive protein could also be detected by western analysis (Fig. 7, lower panel).
Separation of type I and type II protein kinase in germ cells by $D E A E$ cellulose chromatography

Total $\left[{ }^{3} \mathrm{H}\right] \mathrm{CAMP}$ binding and phosphotransferase activity were measured in the eluate from DEAE cellulose columns of cytoplasmic extracts from round spermatids isolated from 
(a)

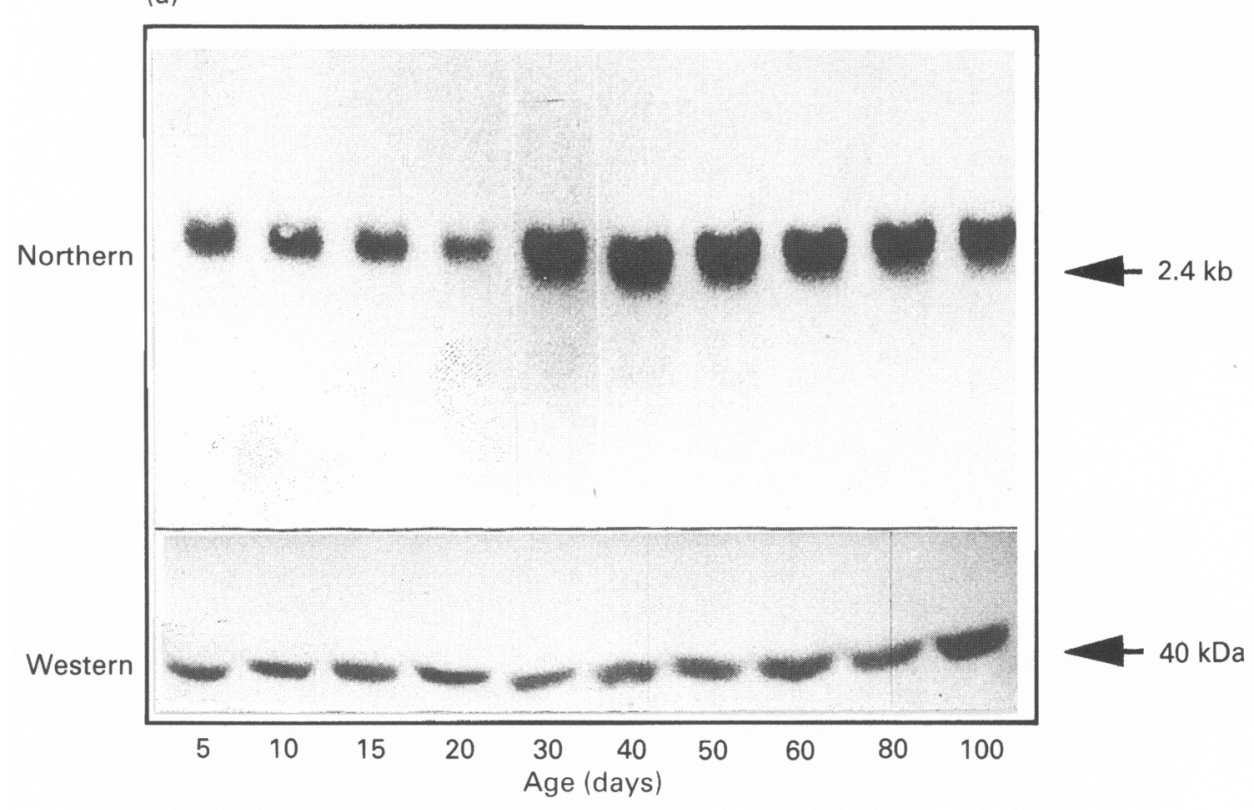

(b)

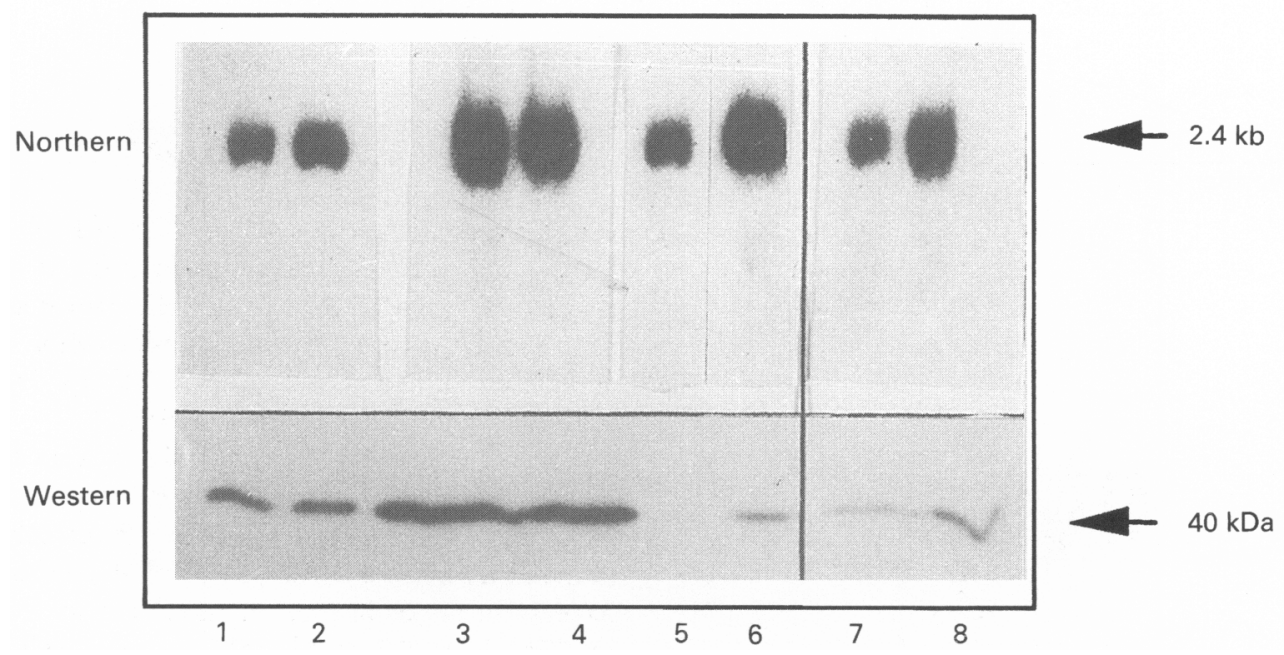

Fig. 5. (a) Age-dependent changes in $C_{\alpha}$ mRNA (northem) and protein (western) in rat testis. Twenty micrograms of total RNA was loaded onto each lane, and the resulting filter was probed with ${ }^{32} \mathrm{P}$-labelled cDNA for $\mathrm{C}_{\alpha}$ and exposed for autoradiography. Soluble proteins were extracted, separated on onedimensional SDS-PAGE (7.5\%, 4.5\% stacking gel), electroblotted to nitrocellulose filters and probed with specific antisera. After radioimmunolabelling, autoradiograms were prepared. (b) Cell-specific distribution of $C_{a}$ mRNA (northern) and protein (western) in rat testis. Lane 1: unstimulated Sertoli cells from 19-day-old rats. Lane 2: Sertoli cells stimulated with dibutyryl cAMP $\left(0.1 \mathrm{mmol}^{-1}\right)$ for $48 \mathrm{~h}$. Lane 3: pachytene spermatocytes from 32-day-old rats. Lane 4: round spermatids from 32-day-old rats. Lane 5: peritubular cells. Lane 6: Leydig cell tumour. Lane 7: testis from 19-day-old rats. Lane 8: testis from 32-day-old rats. Std: purified $C$ from bovine heart.

seminiferous tubules of 32-day-old rats (Fig. 8a). These two activity plots have near identical shapes, showing a peak of activity eluting at $50 \mathrm{mmol}$ salt $1^{-1}$. This is interpreted as a type I kinase, i.e. the binding may be referred to as $\mathrm{RI}_{\alpha}$. Very low activities were measured at higher salt concentrations, and there was almost no evidence of RII $\left[{ }^{3} \mathrm{H}\right]$ cAMP binding or phosphotransferase activities in the region.
DEAE cellulose chromatography of cytoplasmic extracts from a haploid germ cell fraction containing both round spermatids (50\%) and elongating spermatids (45\%) from 44day-old rats revealed a different picture (Fig. 8 b). Two peaks of $\left[{ }^{3} \mathrm{H}\right] \mathrm{cAMP}$ binding and phosphotransferase activity were clearly present, one eluting at $50 \mathrm{mmol} \mathrm{NaCl} l^{-1}$ (type I) and the other at approximately $200 \mathrm{mmol} \mathrm{NaCl}^{-1}$ (type II). Quantitative 


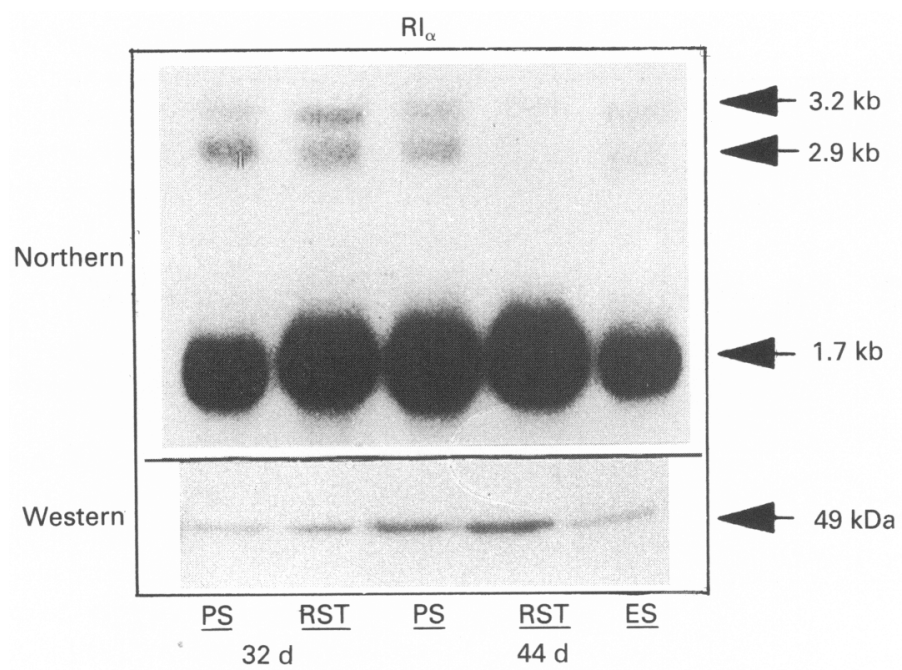

Fig. 6. $\mathrm{RI}_{\alpha}$ mRNA (northern) and protein (western) in pachytene spermatocytes (PS), round spermatids (RST) and elongated spermatids (ES), isolated from 32- and 44-day-old rats. Twenty micrograms of total RNA was loaded onto each lane, and the resulting filter was probed with ${ }^{32} \mathrm{P}$-labelled CDNA for $\mathrm{RI}_{\alpha}$ and exposed for autoradiography. Soluble proteins were extracted, separated on one-dimensional SDS-PAGE $(7.5 \%, 4.5 \%$ stacking gel), electroblotted to nitrocellulose filters and probed with specific antisera. After radioimmunolabelling, autoradiograms were prepared.

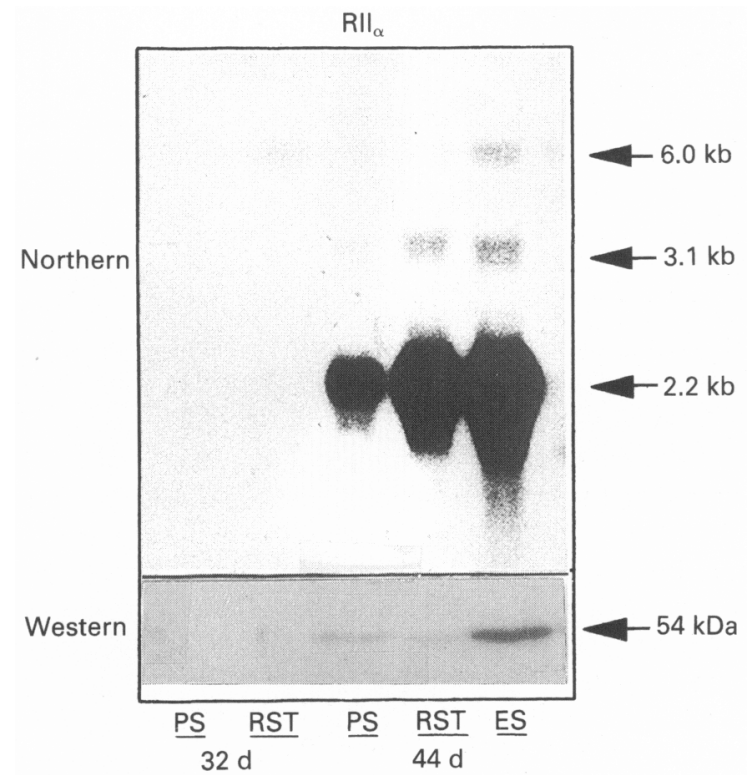

Fig. 7. RII $_{\alpha}$ mRNA (northern) and protein (western) in pachytene spermatocytes (PS), round spermatids (RST) and elongated spermatids (ES), isolated from 32- and 44-day-old rats. Twenty micrograms of total RNA was loaded onto each lane, and the resulting filter was probed with ${ }^{32} \mathrm{P}$-labelled cDNA for $\mathrm{RII}_{\alpha}$ and exposed for autoradiography. Soluble proteins were extracted, separated on one-dimensional SDS-PAGE (7.5\%, 4.5\% stacking gel), electroblotted to nitrocellulose filters and probed with specific antisera. After radioimmunolabelling, autoradiograms were prepared.

estimates by 'immunoimmobilization assay' revealed a $40 \%$ decrease in $\mathrm{RI}_{\alpha}$ (from 13.7 to $8.5 \mathrm{pmol} \mathrm{mg}{ }^{-1}$ ), combined with a sixfold increase in RII ${ }_{\alpha}$ (from 0.3 to $1.9 \mathrm{pmol} \mathrm{mg}^{-1}$ ). The RI:RII ratio changed from 46 in 32 -day-old rats to 4.5 in 44-day-old rats.

\section{Discussion}

This report surveyed the distribution of PKA isoforms of both mRNA and protein during development in the testis and in isolated testicular cells (Sertoli cells, peritubular cells, Leydig cells and germ cells). Additional information was obtained by stimulation of Sertoli cells with cAMP and by purifying germ cells at different stages of differentiation.

The changes in amounts of $R$ and $C$ subunits in extracts of whole rat testis during development may be due to hormonal influences, cellular differentiation or altered cellular composition of the testis. During development in rats, there is an exponential increase in the number of germ cells from 15-25 days of age, resulting in a relative dilution of somatic cells. There is a concurrent differentiation of the germ cells through the meiotic divisions, and after 40 days of age elongating spermatids appear. Changes observed at these ages may, to a great extent, be attributed to changes in the cell composition in the testis. It should not be taken for granted that mRNA/protein content of cultured cells reflects the situation in vivo. However, our results on cell-specific expression for each of the subunits are compatible with the developmental changes observed and the known alteration in cell composition in rat testis of various ages (Claussen et al., 1978).

The appearance of small mRNAs in whole testis have previously been reported for $\mathrm{RI}_{\alpha}(1.7 \mathrm{~kb}$ ) (Øyen et al., 1987b) and $\mathrm{RII}_{\alpha}(2.2 \mathrm{~kb})$ (Øyen et al., 1988b) and these mRNAs are formed by the use of alternative polyadenylation site signals (Øyen et al., 1990). The cell specificity studies reported here convincingly demonstrate that these bands are germ-cell specific.

The most dense bands that appeared on the autoradiograms in this study were the small mRNA bands that are associated with germ cells. It is not known to what extent the various 

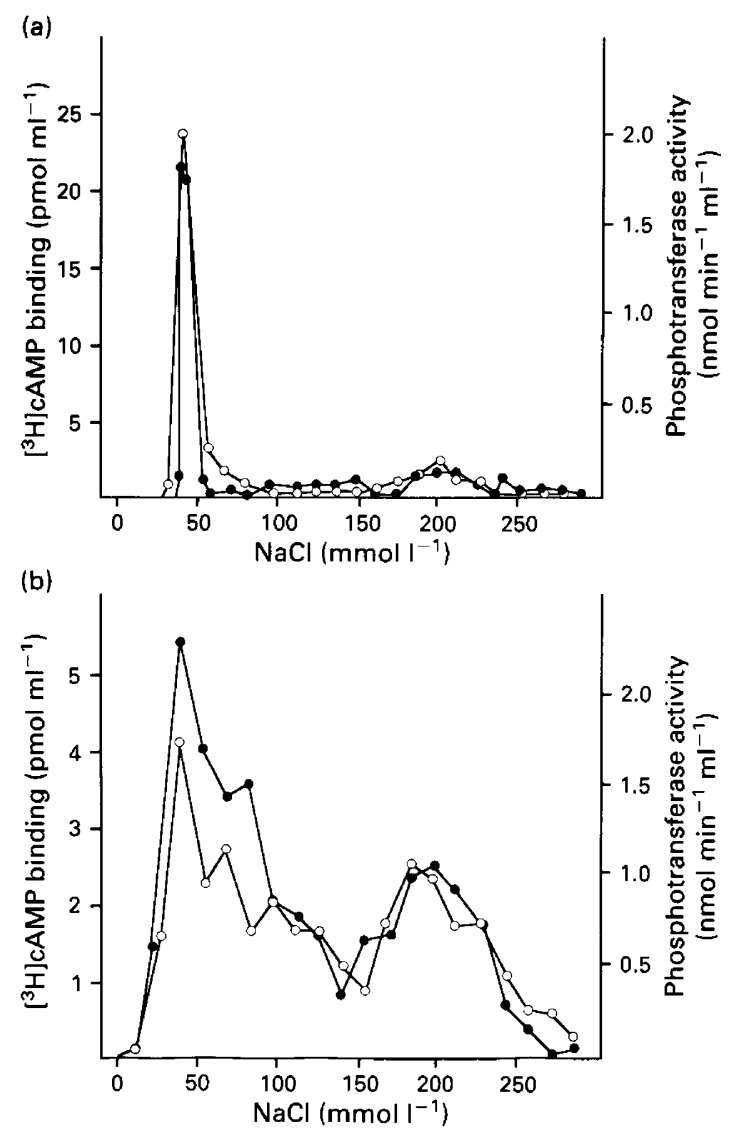

Fig. 8. DEAE cellulose chromatography of cytoplasmic extracts from round spermatids of (a) 32-day-old and (b) 44-day-old rats. Extracts were applied to DEAE-cellulose columns (Whatman DE52) and eluted by a linear $\mathrm{NaCl}$ gradient $\left(0-400 \mathrm{mmol} \mathrm{NaCl} \mathrm{l}^{-1}\right)$. Fractions of $1 \mathrm{ml}$ were collected, and every second sample was assayed for $\left[{ }^{3} \mathrm{H}\right] \mathrm{cAMP}$ binding (O) and phosphotransferase activity $(O)$.

mRNA species detected by specific $\mathrm{CDNA}$ probes contribute to the protein end product. All the mRNA bands indicated, including the shortest, have a length that may encompass the entire open reading frame. Comparison with similar western filters indicates that these can all be translated. On the cell specificity filters, the high molecular weight mRNA bands are found in Sertoli cells, and protein products are simultaneously present. The small mRNAs for $\mathrm{RI}_{\alpha}$ and $\mathrm{RII}_{\alpha}$ appear to be translated in that the amount of protein for these subunits increased on the age filters (Figs $2 a$ and $3 a$ ) and the only mRNA bands that increased were the small bands. The increase in total $\left[{ }^{3} \mathrm{H}\right] \mathrm{CAMP}$ binding can therefore largely be attributed to the translation of small forms of $\mathrm{RI}_{\alpha}$ and $\mathrm{RII}_{a}$ mRNAs. There is, however, a clear discrepancy between the vast increases in signal intensities for the $\mathrm{RI}_{\alpha}(1.7 \mathrm{~kb})$ and $\mathrm{RII}_{\alpha}(2.2 \mathrm{~kb}) \mathrm{mRNA}$ on the age studies and the changes in their respective protein content. On the cell specificity filter for $\mathrm{RI}_{\alpha^{\prime}}$ the protein bands detected by western analysis revealed similar variation in intensity to the two larger (for $\mathrm{RI}_{\alpha}: 3.2,2.9 \mathrm{~kb}$ ) mRNA bands, but not to the small-sized mRNA (1.7 kb). This result may indicate a lower translational efficiency of the low versus the high molecular weight mRNAs.

It is not known what purpose the large amounts of small mRNA species serve in germinal cells. One possibility is that the small mRNAs for $\mathrm{RI}_{\alpha}$ and $\mathrm{RI}_{\alpha}$ are specifically adapted to the transcription/translation machinery of the germ cells. They may also represent a storage form of these mRNAs to be translated in elongating spermatids after transcription has stopped.

An association between the regulatory subunit $\mathrm{RII}_{\alpha}$ and mammalian sperm flagellum has been reported by Horowitz et al. (1989) and Conti et al. (1983). In this report, early stages of germ cell development (pachytene spermatocytes, round spermatids) contain virtually only $\mathrm{RI}_{\alpha}$, thus making these classes of germ cell the most RI-specific cells known. The decrease in $\mathrm{RI}_{\alpha}$ and the increase in $\mathrm{RII}_{\alpha}$ during spermatid elongation (this study and Conti et al., 1983) indicate that these subunits of PKA may have distinct functions in germ cells and spermatozoa. However, phosphorylation by PKA of axokinin (probably RII $_{\alpha}$ ) is not only required for sperm motility (at a stage when transcriptional activity has terminated) but is also sufficient for activation of motility (Tash et al., 1986).

$\mathrm{RI}_{\alpha}$ and $\mathrm{RII}_{\beta}$ are both stimulated by cAMP in Sertoli cells at the mRNA and protein level (Øyen et al., 1987a; Landmark et al., 1991). In spite of this they show completely different changes during development at both the mRNA and protein levels. The reason for this is probably the different cellular location and the fact that amounts of $\mathrm{RII}_{\beta} \mathrm{mRNA}$ and protein are much more influenced by FSH and cAMP than is $\mathrm{RI}_{\alpha}$. The age-dependent decline in $\mathrm{RII}_{\beta}$ protein during development is most likely a result of the relative increase in germ cells during this period. The increase in $\mathrm{RI}_{\alpha}$ protein during the same period strongly indicates that the germ cell specific ( $1.7 \mathrm{~kb}) \mathrm{mRNA}$ is translated (see above).

In previous studies, in which type I and type II PKA kinase activities were measured in Sertoli cells, the response to cAMP treatment has been interpreted as an increase in type I PKA (Nistico et al., 1991). However, if one separates the type II PKA into $\mathrm{RII}_{\alpha}$ and $\mathrm{RII}_{\beta}$, the modest increase in type II kinase after dibutyryl-cAMP stimulation can be attributed to the appearance of $\mathrm{RII}_{\beta}$, which is not detectable in unstimulated cells (Landmark et al., 1991). Thus, the appearance of a new subunit of PKA is easily overlooked.

With the cell specificity filter used in this study, $\operatorname{RII}_{\alpha}$ mRNA was below the level of detection in unstimulated Sertoli cells. The presence of RII in these Sertoli cells is readily shown by a longer time of exposure. Furthermore, $\mathrm{RII}_{\alpha}$ mRNA was stimulated by cAMP in Sertoli cells. However, a similar increase could not be demonstrated at the protein level. A reason for this may be that free $R$ (and C) subunits are degraded faster than holoenzyme subunits (Flockhart et al., 1982). Thus, an increase in protein following cAMP stimulation will be observed only if the increase in translation exceeds the accelerated degradation. The peritubular cells had the highest amount of $6.0 \mathrm{~kb}$ mRNA for $\mathrm{RII}_{\alpha^{\prime}}$ but the protein content on western analysis was of similar intensity to that of Sertoli cells and whole testis. This result may indicate that there are cell-specific differences in translational efficiencies or in R subunit stability. In Leydig cell tumour in this study the $\mathrm{RII}_{\alpha}$ protein was apparently partly degraded, whereas $\mathrm{RI}_{\alpha}$ and $\mathrm{RII}_{\beta}$ were not. This may indicate that $\mathrm{RII}_{a}$ is more susceptible to proteolytic cleavage.

The multiplicity of PKA subunits, with cell-specific distribution and differential regulation (Cadd and McKnight, 1990; Lonnerberg et al., 1992) strongly indicates that different functions of cAMP may be mediated via distinct isomeric forms of 
PKA (Øyen et al., 1990; Scott, 1991; Lonnerberg et al., 1992). There is experimental evidence for this contention in other cell systems (Skălhegg et al., 1992b; Lanotte et al., 1991).

\section{References}

Atherton RW, Khatoon S, Schoff PK and Haley BE (1985) A study of rat epididymal sperm adenosine $3^{\prime}, 5^{\prime}$-monophosphate-dependent protein kinases: maturation differences and cellular location Biology of Reproduction 32 155-171

Beebe SJ and Corbin JD (1986) Cyclic nucleotide-dependent protein kinases. In The Enzymes, pp 43-11I Ed. PD Boyer and EG Krebs. Academic Press, Orlando

Beebe SJ, Oyen O, Sandberg M, Froysa A, Hansson V and Jahnsen T (1990) Molecular cloning of a tissue-specific protein kinase $\left(C_{\gamma}\right)$ from human testis representing a third isoform for the catalytic subunit of CAMP-dependent protein kinase Molecular Endocrinology 465-475

Bradford MM (1976) A rapid and sensitive method for the quantitation of microgram quantities of protein utilizing the principle of protein-dye binding Analytical Biochemistry 72 248-254

Cadd G and McKnight SM (1990) Distinct patterns of cAMP-dependent protein kinase gene expression in mouse brain Neuron 3 71-79

Claussen OPF, Purvis K and Hansson V (1978) Endocrine correlates of meiosis in the male rat Archives of Andrology 2 59-66

Cobb CE and Corbin JD (1988) Purification of CAMP-free and CAMP-bound forms of bovine heart cAMP-dependent protein kinase holoenzyme. In Methods in Enzymology, pp 202-208 Ed. JD Corbin and RA Johnson. Academic Press, San Diego

Conti M, Adamo S, Geremia R and Monesi V (1983) Developmental changes of cyclic adenosine monophosphate-dependent protein kinase activity during spermatogenesis in the mouse Biology of Reproduction 28 860-869

Corbin JD, Keely SL and Park CP (1975) The distribution and dissociation of cyclic adenosine $3^{\prime}, 5^{\prime}$-monophosphate-dependent protein kinases in adipose, cardiac, and other tissues Journal of Biological Chemistry 250 218-225

Corbin JD, Sugden PH, West $L$, Flockhart DA, Lincoln TM and McCarthy D (1978) Studies on the properties and mode of action of the purified regulatory suburit of bovine heart adenosine $3^{\prime}, 5^{\prime}$-monophosphate-dependent protein kinase Journal of Biological Chemistry 253 3997-4003

Corbin JD, Ogreid D, Miller JP, Suva RH, Jastorff BS and Deskeland SO (1986) Studies of cGMP analog specificity and function of the two intrasubunit binding sites of cGMP-dependent protein kinase Joumal of Biological Chemistry 261 1208-1214

Dorrington JH, Roller NF and Fritz IJ (1975) Effects of follicle stimulating hormone on cultures of Sertoli cell preparations Molecular and Cellular Endocrinology 3 57-70

Ekanger R, Vintermyr OK and Doskeland SO (1988) The amounts of rat liver cyclic AMP-dependent protein kinase I and II are differentially regulated by diet Biochemical Journal 256 447-452

Erichsen AA, Jahnsen T, Attramadal A and Hansson V (1984) A transplantable rat Leydig cell tumour. 2. Adenylyl cyclase activation by prostaglandin EI, isoproterenol and glucagon joumal of Steroid Biochemistry $12 \quad 315-322$

Fakunding JL and Means AR (1977) Characterization and follicle stimulating hormone activation of Sertoli cell cyclic AMP-dependent protein kinases Endocrinology 101 1358-1368

Fleischer N, Rosen OM and Reichlin M (1976) Radioimmunoassay of bovine heart protein kinase Proceedings of the National Academy of Sciences, USA $\mathbf{7 3}$ $54-58$

Flockhart DA and Corbin JD (1982) Regulatory mechanisms in the control of protein kinases CRC Critical Reviews of Biochemistry 12 133-186

Garbers DL and Kopf GS (1980) The regulation of spermatozoa by calcium and cyclic nucleotides. In Advances in Cyclic Nucleotide Research, pp 251-306 Ed. P Greengard and GA Robison. Academic Press, New York

Horowitz JA, Toeg H and Orr G (1984) Characterization and localization of cAMP-dependent protein kinases in rat caudal epididymal sperm Journal of Biological Chemistry 259 832-838

Horowitz JA, Voullalas V, Wasco W, Macleod J, Paupard M-C and Orr GA (1989) Biochemical and immunological characterization of the flagellarassociated regulatory subunit of a type II cyclic adenosine 5 -monophosphatedependent protein kinase Archives of Biochemistry and Biophysics 270 $411-418$
Hyne RV and Garbers DL (1979) Calcium-dependent increase in adenosine 3', $5^{\prime}$ monophosphate and induction of the acrosome reaction in guinea pig spermatozoa Proceedings of the National Academy of Sciences, USA 76 5699-5703

Jahnsen T, Lohmann SL, Walter U, Hedin L and Richards JS (1985) Purification and characterization of hormone-regulated isoforms of the regulatory subunit of type Il cAMP-dependent protein kinase from rat ovaries Joumal of Biological Chemistry $26015980-15987$

Jahnsen T, Hedin L, Kidd VJ, Beattie WG, Lohmann SM, Walter U, Durica J, Schulz TZ, Schiltz E, Browner M, Lawrence CB, Goldman D, Ratoosh SL and Richards JS (1986) Molecular cloning, cDNA structure, and regulation of the regulatory subunit of type II cAMP-dependent protein kinase from rat ovarian granulosa cells Journal of Biological Chemistry 261 12352-12361

Kuno T, Ono Y, Hirai M, Hashimoto S, Shuntoh H and Tanaka C (1987) Molecular cloning and cDNA structure of the regulatory subunit of type I cAMP-dependent protein kinase from rat brain Biochemical and Biophysical Research Communications 146 878-883

Laemmli UK (1970) Cleavage of structural proteins during the assembly of the head of bacteriophage T4 Nature 227 680-685

Landmark BF, Fauske B, Eskild W, Skälhegg BS, Lohmann SM, Hansson V, Jahnsen $T$ and Beebe $S$ (1991) Identification, characterization, and hormonal regulation of $3^{\prime}, 5^{\prime}$-cyclic adenosine monophosphate-dependent protein kinases in rat Sertoli cells Endocrinology 129 2345-2354

Lanotte M, Riviere JB, Hermouet S, Houge G, Vintermyr OK, Gjertsen BT and Doskeland SO (1991) Programmed cell death (apoptosis) is induced rapidly and with positive cooperativity by activation of cyclic adenosine monophosphate-kinase I in a myeloid leukemia cell line Journal of Cellular Physiology $14673-80$

Lohmann SM, Schwoch G, Reiser G, Port R and Walter U (1983) Dibutyryl cAMP treatment of neuroblastome-glioma hybrid cells results in selective increase in cAMP-receptor protein (RI) as measured by monospecific antibodies $E M B O$ Journal 2 153-159

Lonnerberg P, Parvinen M, Jahnsen T, Hansson V and Persson H (1992) Stage. and cell-specific expression of cAMP-dependent protein kinases in rat seminiferous epithelium Biology of Reproduction 46 1057-1068

Maniatis T, Fritsch EF and Sambrook J (1983) In Molecular Cloning (A Laboratory Manual), p 196. Cold Spring Harbor, New York

Massa JS, Fellows RE and Maurer RA (1990) Rat $\mathrm{RI}_{\beta}$ isoform of type I regulatory subunit of cyclic adenosine monophosphate-dependent protein kinase: cDNA sequence analysis, mRNA tissue specificity, and rat/mouse difference in expression in testis Molecular Reproduction and Development 26 129-133

Means AR, Dedman JR, Tash JS, Tindall DJ, van Sicle M and Welsh MJ (1980) Regulation of the testis Sertoli cell by follicle-stimulating hormone Annual Review of Physiology 42 59-79

Nistico L, Pezzotti R and Galdieri M (1991) Cyclic adenosine 3',5'-monophosphate (cAMP)-dependent protein kinase activity in the somatic cells of the seminiferous tubules. I. Isoform analysis Cellular and Molecular Biology 37 325-335

Oyen O, Eskild W, Froysa A, Sandberg M, Levy FO, Knutsen G, Hansson V and Jahnsen $T$ (1987a) Hormonal regulation and age-dependent changes in mRNA levels for regulatory subunits of cAMP-dependent protein kinases in rat testis. In Cell Biology of the Testis and Epididymis, pp 473-476. Academy of Sciences, New York

Øyen O, Frøysa A, Sandberg M, Eskild, W, Joseph D, Hansson V and Jahnsen T (1987b) Cellular localization and age-dependent changes in mRNA for cyclic adenosine $3^{\prime}, 5^{\prime}$-monophosphate-dependent protein kinases in rat testis Biology of Reproduction 37 947-956

Øyen O, Sandberg M, Eskild W, Levy FO, Knutsen G, Beebe SJ, Hansson V and Jahnsen T (1988a) Differential regulation of messenger ribonucleic acids for specific subunits of cyclic adenosine $3^{\prime}, 5^{\prime}$-monophosphate (cAMP)-dependent protein kinase in rat Sertoli cells Endocrinology 122 2658-2666

Øyen O, Scott JD, McKnight SM, Krebs EG, Hansson V and Jahnsen T (1988b) A unique mRNA species for a regulatory subunit of cAMP-dependent protein kinase is specifically induced in haploid germ cells Federation of European Biochemical Societies 229 391-394

Øyen O, Myklebust F, Scott JD, Cadd GC, McKnight SM, Hansson V and Jahnsen T (1990) Subunits of CAMP-dependent protein kinase show differential and distinct expression patterns during germ cell differentiationalternative polyadenylation in germ cells gives rise to unique smaller-sized mRNA species Biology of Reproduction 43 46-54

Podesta, EJ, Dufau ML and Catt KJ (1976) Characterization of two forms of cyclic $3^{\prime}, 5^{\prime}$-adenoxine monophosphate-dependent protein kinase in rat testicular interstitial cells Molecular and Cellular Endocrinology 5 109-122 
Robison GA, Butcher RW and Sutherland EW (1971) Cyclic AMP. Academic Press, New York

Sandberg M, Levy FO, Oyen O, Hansson V and Jahnsen T (1988) Molecular cloning, cDNA structure and deduced amino acid sequence for the hormoneinduced regulatory subunit $\left(\mathrm{RII}_{B}\right)$ of cAMP-dependent protein kinase from rat ovarian granulosa cells Biochemical and Biophysical Research Communications 154 705-711

Scott JD (1991) Cyclic nucleotide-dependent protein kinases. In Pharmacology and Therapeutics, pp 123-145 Ed CW Taylor. Pergamon Press, Oxford

Scott JD, Glaccum MB, Zoller MJ, Uhler MD, Helfman DM, McKnight SM and Krebs EG (1987) The molecular cloning of a type II regulatory subunit of the cAMP-dependent protein kinase from rat skeletal muscle and mouse brain Proceedings of the National Academy of Sciences, USA 84 5192-5196

Skälhegg BS, Landmark B, Foss KB, Lohmann SM, Hansson V and Lea T (1992a) Identification, purification and characterization of subunits of cAMPdependent protein kinase in human testis. Reverse mobilities of human $\mathrm{RII}_{\alpha}$ and $\mathrm{RII}_{\beta}$ on SDS-PAGE compared with rat and bovine RIls Joumal of Biological Chemistry 267 5374-5379

Skälhegg BS, Landmark BF, Doskeland SO, Hansson V and Jahnsen T (1992b) Cyclic AMP-dependent protein kinase type I mediates the inhibitory effects of $3^{\prime}, 5^{\prime}$-cyclic adenosine monophosphate on cell replications in human $T$ lymphocytes Journal of Biological Chemistry 267 15707-15714

Spruill WA, Steiner AL, Tres LL and Kierszenbaum AL (1984) Characterization of cyclic AMP-binding proteins in rat Sertoli cells using a photoaffinity ligand Molecular and Cellular Biochemistry 60 147-157

Tash IS and Means AR (1983) Cyclic adenosine 3',5' monophosphate, calcium and protein phosphorylation in flagellar motility Biology of Reproduction $\mathbf{2 8}$ 75-104
Tash JS, Kakar SS and Means AR (1984) Flagellar motility requires the cAMPdependent phosphorylation of a heat-stable NP-40-soluble $56 \mathrm{kd}$ protein axokinin Cell 38 55I-559

Tash JS, Hidaka H and Means AR (1986) Axokinin phosphorylation by cAMPdependent protein kinase is sufficient for activation of sperm flagellar motility Joumal of Cell Biology 103 649-655

Towbin H, Staehelin T and Gordon J (1988) Electrophoretic transfer of proteins from polyacrylamide gels to nitrocellulose sheets: procedure and some applications Proceedings of the National Academy of Sciences, USA 76 4350-4354

Uhler MD, Carmichael DF, Lee DC, Chrivia JC, Krebs EG and McKnight SM (1986) Isolation of $\mathrm{cDNA}$ clones coding for the catalytic subunit of mouse cAMP-dependent protein kinase Proceedings of the National Academy of Sciences, USA 83 1300-1304

Visconti PE and Tezòn JG (1992) Phorbol esters stimulate cyclic adenosine $3^{\prime}, 5^{\prime}$-monophosphate accumulation in hamster spermatozoa during in vitro capacitation Biology of Reproduction $\mathbf{4 0}$ 223-231

Wiemann S, VoB H, Kinzel V and Pyerin W (1991) Rat $C_{\alpha}$ catalytic subunit of the CAMP-dependent protein kinase: CDNA sequence and evidence that it is the only isoform expressed in myoblasts Biochimica et Biophysica Acta $\mathbf{1 0 8 9}$ 254-256

Winters CA and Dufau ML (1984) Characterization of Leydig cell protein kinase. Further studies in hormone action FEBS Letters 178 73-78 